\title{
Reduced neuronal population in the dorsolateral prefrontal cortex in infant macaques infected with simian immunodeficiency virus (SIV)
}

\author{
Alexandra Haddad ${ }^{1} \cdot$ Brittany Voth $^{1} \cdot$ Janiya Brooks ${ }^{1} \cdot$ Melanie Swang ${ }^{1} \cdot$ Heather Carryl ${ }^{1}$. Norah Algarzae ${ }^{1,4}$. \\ Shane Taylor ${ }^{1} \cdot$ Camryn Parker $^{1} \cdot$ Koen K. A. Van Rompay ${ }^{2} \cdot$ Kristina De Paris $^{3} \cdot$ Mark W. Burke $^{1}$
}

Received: 27 April 2021 / Revised: 11 August 2021 / Accepted: 26 August 2021 / Published online: 23 September 2021

(C) The Author(s) 2021

\begin{abstract}
Pediatric HIV infection remains a global health crisis with an estimated 150,000 new mother-to-child (MTCT) infections each year. Antiretroviral therapy (ART) has improved childhood survival, but only an estimated 53\% of children worldwide have access to treatment. Adding to the health crisis is the neurological impact of HIV on the developing brain, in particular cognitive and executive function, which persists even when ART is available. Imaging studies suggest structural, connectivity, and functional alterations in perinatally HIV-infected youth. However, the paucity of histological data limits our ability to identify specific cortical regions that may underlie the clinical manifestations. Utilizing the pediatric simian immunodeficiency virus (SIV) infection model in infant macaques, we have previously shown that early-life SIV infection depletes the neuronal population in the hippocampus. Here, we expand on these previous studies to investigate the dorsolateral prefrontal cortex (dlPFC). A total of 11 ART-naïve infant rhesus macaques (Macaca mulatta) from previous studies were retrospectively analyzed. Infant macaques were either intravenously (IV) inoculated with highly virulent SIVmac251 at $\sim 1$ week of age and monitored for 6-10 weeks or orally challenged with SIVmac251 from week 9 of age onwards with a monitoring period of 10-23 weeks post-infection (19-34 weeks of age), and SIV-uninfected controls were euthanized at 16-17 weeks of age. Both SIV-infected groups show a significant loss of neurons along with evidence of ongoing neuronal death. Oral- and IV-infected animals showed a similar neuronal loss which was negatively correlated to chronic viremia levels as assessed by an area under the curve (AUC) analysis. The loss of dIPFC neurons may contribute to the rapid neurocognitive decline associated with pediatric HIV infection.
\end{abstract}

Keywords Pediatric HIV $\cdot$ Dorsolateral prefrontal cortex $\cdot$ Stereology $\cdot$ Neurodevelopment

\section{Introduction}

Alexandra Haddad, Brittany Voth, and Janiya Brooks share equal contribution.

Mark W. Burke

mark.burke@howard.edu

1 Department of Physiology and Biophysics, Howard University, Washington, DC 20059, USA

2 California National Primate Research Center, University of California Davis, Davis, CA 95616, USA

3 Department of Microbiology and Immunology, University of North Carolina, Chapel Hill, NC 27599, USA

4 King Saudi University, Riyadh, Riyadh, Kingdom of Saudi Arabia
In 2015, the UNAIDS 90-90-90 initiative was launched to reduce the impact of the AIDS epidemic by having $90 \%$ of people with HIV being diagnosed, $90 \%$ on sustained antiretroviral therapy (ART), and 90\% of people on ART having viral suppression by 2020 (UNAIDS-2014, 2014). However, these goals were not met in the pediatric population (aged 0-14 years) (UNAIDS 2020). Nonetheless, this past decade has seen a significant decrease in the reported worldwide number of pediatric HIV infections, with an estimated 150,000 new pediatric HIV infections in 2019, which is half the number that was reported in 2010 (UNAIDS 2020). Maternal ART and avoidance of mixed feeding practices prior to 6 months of age have been integral to the reduction of mother-to-child transmission (MTCT) (Becquet et al. 2009; Becquet et al. 2008; Rollins et al. 2013; 
Zash et al. 2016). Despite this advancement, children still represent $13 \%$ of the new infections in sub-Saharan Africa and $4 \%$ of global infections with the total of new pediatric infections remaining steady over the past several years (UNAIDS 2020). Globally, coverage of pediatric ART treatment is lower than that of adults, with only about $53 \%$ of HIV + children receiving treatment, leaving about 840,000 HIV + children in need of treatment (UNAIDS 2020). Although ART results in increased survival rates among HIV-infected children (Brady et al. 2010; Dowshen and D'Angelo 2011; Sohn and Hazra 2013), neurodevelopmental deficits persist (van Arnhem et al. 2013; Van Rie et al. 2007, 2008) which are compounded by the lack of ART availability (UNAIDS 2020) and challenges of ART adherence in adolescent populations (MacDonell et al. 2013; Mofenson and Cotton 2013).

Perinatally HIV-infected (pHIV) children consistently present with a higher prevalence of neurological impairment than infected adults despite controlled viremia with ART (Cohen et al. 2015; Phillips et al. 2016). Neuropsychological evaluations suggest that pHIV children display deficits in planning/reasoning, cognitive ability, motor proficiency, working memory, attention/impulsivity, IQ, and executive function (Boivin et al. 2019; Cohen et al. 2015; Nichols et al. 2016; Phillips et al. 2016; Van den Hof et al. 2019b). The neurodevelopmental sequelae of pHIV children have long-term consequences. As pHIV children transition into adolescence, planning and reasoning (Boivin et al, 2019) and executive function deficits remain (Nichols et al. 2016; Van den Hof et al. 2020). Likewise, deficits persist into adulthood with information processing speed, working memory, verbal fluency, and global cognition domains affected in pHIV adults despite being on an ART regimen (Coutifaris et al. 2020; Willen et al. 2017). Direct HIV infection of the central nervous system (CNS), systemic inflammation, and ART regimens have been implicated in pHIV neurologic impairment (Hoare et al, 2020; Musielak and Fine 2016); however, the extent of neurodevelopmental alterations and its relation to the neuropsychological manifestations remains elusive (Carryl et al. 2015; Van den Hof et al. 2019a). Imaging studies have provided evidence of CNS structural and functional differences in pHIV children, including alterations in cerebrovascular flow (Blokhuis et al. 2017; Dean et al. 2020), white matter (Ackermann et al. 2014, 2016, 2019; Donald et al. 2015; Hoare et al. 2015a, b, 2012a, b; Sarma et al. 2019, 2014), gray matter (Cohen et al. 2016; Lewis-de Los Angeles et al. 2017; Sarma et al. 2014), and decreased total brain volumes (Dean et al. 2020). Altered functional connectivity has been reported in the left middle temporal gyrus, postcentral gyrus, and middle frontal gyrus, potentially affecting auditory and visual coordination, sensory network, and cognitive networks, respectively (Yadav et al. 2017, 2018). Imaging and neuropsychological assessments indicate that the prefrontal cortical network, at least in part, is involved in the cognitive deficits in pHIV (Goldman-Rakic. 1995a, 1996; Herting et al. 2015; Levy and Goldman-Rakic 1999; McCarthy et al. 1996; Rajkowska and Goldman-Rakic. 1995a, b).

Although imaging data suggests an altered prefrontal cortical network, these studies lack the sensitivity to identify alterations at the cellular level and characterize the pathophysiology of pHIV. The scarce pathology reports suggest cortical apoptosis (Gelbard et al. 1995) and an active role of astrocytes in the neuropathogenesis in pHIV infection (Blumberg et al. 1994; Saito et al. 1994; Tornatore et al. 1994; Trillo-Pazos et al. 2003). One of the main obstacles in pHIV research is sample access necessitating animal model systems to investigate the pathogenesis of HIV in the developing brain (Carryl et al. 2015; McLaurin et al. 2017a, b, 2018a, b, 2020, 2017c; Moran et al. 2019). The HIV-1 transgenic rat (HIVTg), which expresses 7 of the 9 HIV-1 proteins throughout its lifespan, including the developmental period, has shown deficits in temporal processing (Moran et al. 2013), attention, and executive function components of inhibition and flexibility (Moran et al. 2014a). Further supporting the vulnerability of the frontal cortex, HIVTg animals display altered morphology of pyramidal neuronal dendritic spines of layers II-III in the medial prefrontal cortex (McLaurin et al. 2018b). While rodent models have primarily focused on the effects of viral proteins on the developing brain (McLaurin et al, 2017a, b, 2018a, b; Moran et al. 2014b), the neuropathogenic effects of pHIV infection are not recapitulated in these models (Carryl et al.2015).

The pediatric simian immunodeficiency virus (SIV) model complements rodent models since macaques have a similar developmental pattern (both immune and neurodevelopment) to humans. Additionally, SIV and HIV-1 have similar pathogenesis, routes of transmission, immune suppression, and disease progression (Abel 2009; Carryl et al. 2015; Clancy et al. 2001; Nowakowski and Rakic 1981). Furthermore, MTCT can occur by the same routes in rhesus macaques and humans, and we have recently shown that within $96 \mathrm{~h}$ of oral SIVmac251 administration, viral RNA and DNA can be detected in the cerebral cortex (Abel 2009; Amedee et al. 2018). Subjects that either received intravenous SIVmac251 within 1 week of age or were orally challenged at 9 weeks of age displayed a significant loss of neurons throughout the CA subfields (CA1-3) (Carryl et al. 2017; Curtis et al. 2014) along with reduced immature neuronal population in the dentate gyrus (Curtis et al. 2014). While the hippocampus is a key component of the cognitive network (Friedman and GoldmanRakic. 1988; Lisman et al. 2017), deficits within this area cannot alone account for the cognitive and executive deficits. Available clinical evidence (Boivin et al. 2019; Cohen et al. 2015; Nichols et al. 2016; Phillips et al. 2016; Van 
den Hof et al. 2019a; Van den Hof et al. 2019b) suggests involvement of the prefrontal cortex, in particular the dorsolateral prefrontal cortex (dlPFC) which lies within the superior and middle frontal gyri in humans and the principle sulcus in non-human primates (Friedman and GoldmanRakic, 1988; Goldman-Rakic 1995a, 1996; Levy and Goldman-Rakic 1999; McCarthy et al. 1996; Petrides and Pandya 1999; Rajkowska and Goldman-Rakic 1995a, b); however, this area is relatively unexplored in models of pHIV. Here, we identify the effects of pediatric SIV infection on the neuronal population in the dIPFC.

\section{Methods}

\section{Subjects and procedures}

Infant macaques (Macacca mulatta) born to SIV-naïve dams were nursery-reared at the California National Primate Research Center (CNPRC) in accordance with the American Association for Accreditation of Laboratory Animal Care Standards. Subjects in the current study were part of previously conducted studies (Jensen et al. 2017, 2016, 2013, 2012) with all procedures approved by the University of California at Davis Institutional Animal Care and Use Committee. Briefly, a total of 12 infant rhesus macaques were included in this study consisting of (1) an intravenously SIVmac251-inoculated neonatal group (1 inoculation with 1000 median tissue culture infectious dose $\left(\mathrm{TCID}_{50}\right)$ at $\sim 1$ week of age; IV group, $n=3$ ) with a monitoring time of 6-10 weeks, (2) an orally SIVmac251inoculated group (PO group, $n=5$ ) that received weekly low-dose SIVmac251 regimen $\left(5000 \mathrm{TCID}_{50}\right)$ starting around 9 weeks of age until infected with a monitoring time of 10-23 weeks post-infection, and (3) an SIV-naïve control group $(n=4)$ that was euthanized between 16 and 17 weeks of age (Table 1). SIVmac251 was obtained from the Analytical Resource Core at the CNPRC (Abel 2009), and plasma viral loads were determined from weekly blood samples and quantified by real-time reverse transcription polymerase chain reaction (Cline et al. 2005; Jensen et al. 2016). All animal procedures were performed under ketamine- $\mathrm{HCl}$ anesthesia $(10 \mathrm{mg} / \mathrm{kg}$ i.m.; ParkeDavis, Morris Plains, NC). Sample collections, sample processing, and euthanasia were performed as previously described (Jensen et al. 2016, 2012).

\section{Histology}

Immediately following euthanasia, brains were extracted, fixed in $10 \%$ formalin, blocked into 1-cm slabs, cryoprotected in graded sucrose $(10-30 \%)$, frozen at $-65^{\circ} \mathrm{C}$ in isopentane, and stored at $-80^{\circ} \mathrm{C}$ until further processing (Carryl et al, 2017; Curtis et al. 2014). Blocks of tissue were then systematically sectioned in the coronal plane $(50 \mu \mathrm{m})$ at $-20{ }^{\circ} \mathrm{C}$ in a Microm cryostat in 10 parallel series. The first series of each block was Nissl-stained with cresyl-violet for design-based stereology. The remaining series of tissue were placed in antigen preserve (50\% ethylene glycol, $1 \%$ polyvinal pyrrolodone in phosphate buffer $\mathrm{pH}=7.4$-PBS), and stored in numbered tubes at $-20^{\circ} \mathrm{C}$ for immunohistochemistry as part of our brain bank (Burke et al. 2009b; Carryl et al. 2017; Curtis et al. 2014).

Table 1 Comparison of control, IV-, and PO-infected groups

\begin{tabular}{|c|c|c|c|c|c|c|}
\hline Group & Subject & Gender & Age of SIV infection & Age at euthanasia & Total infection period & $\begin{array}{l}\text { Plasma SIV } \\
\text { RNA (copies/ } \\
\text { mL) }{ }^{\mathrm{a}}\end{array}$ \\
\hline IV-infected & RM1 & M & 1 week & 10 weeks & 9 weeks & $160,000,000$ \\
\hline IV-infected & RM2 & $\mathrm{F}$ & 1 week & 7 weeks & 6 weeks & $240,000,000$ \\
\hline IV-infected & RM3 & $\mathrm{F}$ & 1 week & 10 weeks & 10 weeks & $650,000,000$ \\
\hline PO-infected & RM4 & $\mathrm{F}$ & 9 weeks & 21 weeks & 12 weeks & $5,800,000$ \\
\hline PO-infected & RM5 & $\mathrm{F}$ & 17 weeks & 27 weeks & 10 weeks & $6,400,000$ \\
\hline PO-infected & RM6 & $\mathrm{F}$ & 10 weeks & 22 weeks & 12 weeks & 380,000 \\
\hline PO-infected & RM7 & $\mathrm{F}$ & 13 weeks & 25 weeks & 12 weeks & $46,000,000$ \\
\hline PO-infected & RM8 & M & 9 weeks & 21 weeks & 12 weeks & $71,000,000$ \\
\hline Control & RM9 & $\mathrm{F}$ & N/A & 16 weeks & N/A & N/A \\
\hline Control & RM10 & M & N/A & 16 weeks & N/A & N/A \\
\hline Control & RM11 & $\mathrm{F}$ & N/A & 15 weeks & N/A & N/A \\
\hline Control & RM12 & $\mathrm{F}$ & N/A & 16 weeks & N/A & N/A \\
\hline
\end{tabular}

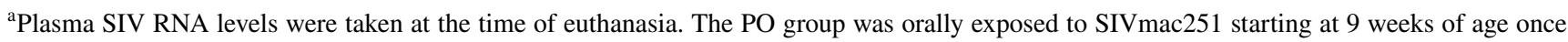
weekly until infection was verified (Jensen et al. 2017, 2016, 2013) 


\section{Design-based stereology}

Quantification of the neuronal population in the dlPFC was achieved using design-based stereology with the optical fractionator method (Burke et al. 2009a; Carryl et al. 2017; Curtis et al. 2014). The dlPFC was delineated on the basis of cytoarchitecture and fiduciary landmarks to include areas 46, 9/46d, and 9/46v (Fig. 1) (Paxinos et al, 2008; Petrides and Pandya, 1999; Petrides et al, 2012). Briefly, the principal sulcus was used as a fiduciary landmark as area 46 occupies the banks of the sulcus and areas 9/46d (dorsal) and 9/46v (ventral) are located on the lips of the sulcus. Cytoarchitecturally, these regions have similar, well-defined layers II, III, IV, and V (Petrides and Pandya 1999) which were used to delineate from adjacent regions. Equidistant sections were sampled throughout the entire rostral-caudal length of this area, and a minimum of two observers were used to delineate each section to ensure consistency between sections and subjects. Sampling parameters for design-based stereology are similar to previously described methods (Carryl et al. 2017; Curtis et al. 2014) where the topography was performed using a $5 \times$ objective and an $x-y$ sampling grid $\left(1000 \mu \mathrm{m}^{2}\right)$ with superimposed counting frames $(16,000$ $\mu \mathrm{m}^{3}$ ) generated through the Stereologer System (Stereology Resource Center, Inc., Tampa, FL, USA). All counting was performed using a plan fluor oil immersion $63 \times$ objective (N.A. 1.4), and every 40th section was counted with a random starting point within the rostral $2000 \mu \mathrm{m}$ of the dIPFC. The Cavalieri estimator was used to determine reference volume of the dlPFC (West and Gundersen 1990). Mean cell volume (MCV) of neurons was simultaneously determined using the nuclear rotator parameter of the Stereologer system, so that neurons that were counted in the total population estimate were also measured as part of the MCV. The total estimation of cell numbers $(N)$ were calculated by the following equation: $N=\mathrm{ssf}^{-1} \times \mathrm{asf}^{-1} \times \mathrm{t}$ $\mathrm{sf}^{-1} \times \Sigma \mathrm{Q}^{-}$. Where ssf is the section sampling fraction, asf is the sampling fraction, tsf is the thickness sampling fraction (where the measured thickness of the tissue is divided by the disector height), and $\Sigma \mathrm{Q}^{-}$is the total number of neurons (defined as having a visible centrally located nucleoli and clearly defined cytoplasm) counted within the dissector (Joelving et al. 2006). MCV was calculated as MCV $=$ mean $l^{3} \times 4 \pi / 3$, where $l$ is the length of the line proportional to the area of the object (Mouton et al. 1994).

\section{Immunohistochemistry}

Standard immunohistochemical techniques were followed for p27 immunohistochemistry, a core protein of SIVmac251 (Higgins et al. 1992). Briefly, matched sections from the dIPFC were removed from the brain bank, washed 3 times in PBS to remove residual antigen preserve. Free-floating sections were then incubated for $20 \mathrm{~min}$ in a $3 \%$ hydrogen peroxide and 20\% methanol solution in PBS to quench endogenous peroxidase activity. Sections were then washed in PBS, blocked in 3\% normal horse serum, and then incubated with mouse anti-SIVmac251 p27 monoclonal antibody (1:200 dilution; NIH AIDS Reagent Program catalog \#1610) overnight at $4{ }^{\circ} \mathrm{C}$. Tissues were then washed in PBS and incubated in biotinylated multilink secondary antibody (BioGenex, \#LP000-ULE) at room temperature for $20 \mathrm{~min}$. Following an additional set of washes in PBS, the sections were then incubated in a streptavidin-horseradish peroxidase solution (BioGenex, \#LP000-ULE) at room temperature for $20 \mathrm{~min}$. Sections were visualized with diaminobenzidine (DAB \#4418, Sigma, St. Louis, MO, USA), mounted on gelatinized slides, dehydrated in graded alcohols (50-100\%), cleared in xylenes, and coverslipped with permount mounting media (Fisher Scientific, \#SP15).
Fig. 1 The rostro-caudal extent area $46 / 9 \mathrm{dv}$ which includes the principle sulcus extending onto the "lips" of the sulcus (Paxinos et al. 2008; Petrides and Pandya 1999; Petrides et al. 2012). The dotted lines demonstrate approximate extent of the counting region. Images are modified from www.BrainMaps.org

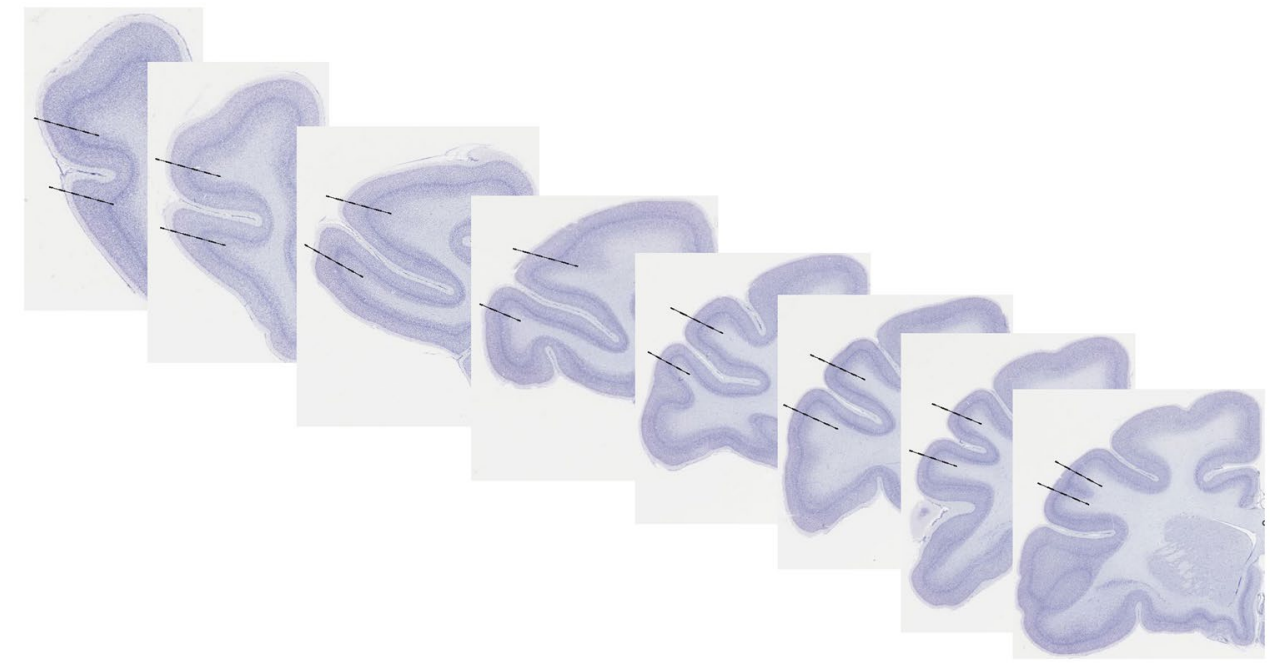




\section{Statistical analysis}

Due to the small group sizes, statistical differences were determined only between two groups at a time applying both one-tailed (Carryl et al. 2017) and two-tailed non-parametric Mann-Whitney $U$ test of significance using the InStat3 program (La Jolla, California, CA, USA). The coefficient of variation $(\mathrm{CV}=\mathrm{SD} /$ mean) was calculated for neuronal population and regional and cell volumes. Coefficients of error (CE) were calculated for total number of neurons to assess the reliability of measurements with average $\mathrm{CE}$ being calculated as $\sqrt{ }$ meanCE $^{2}$. Correlations between neuronal population or neuronal size and SIV viremia were assessed by Spearman rank test using GraphPad Prism version 9.1 (GraphPad, La Jolla, CA).

\section{Results}

Here, we report a comparison of the dlPFC neuronal population, neuronal size, and volume in subjects infected IV with SIVmac251 shortly after birth (within 1 week), PO during the early infancy stage (9-17 weeks of age), and control subjects (Table 1). A set of 8-11 sections spanning the rostralcaudal extent of the dIPFC were sampled with an 1000$\mu \mathrm{m}^{2} x-y$ grid resulting in an average of $277 \pm 52$ disectors per subject (control 312.25 \pm 33.08 ; IV 230.67 \pm 43.25 ; and PO 277.55 \pm 53.33$)$. The average TSF was similar between groups (control 17.42 $\pm 1.72 \mu \mathrm{m}$; IV $16.94 \pm 0.68 \mu \mathrm{m}$; and PO $15.18 \pm 0.77 \mu \mathrm{m})$.

Pediatric SIV infection resulted in a decrease in the total neuronal population of the dIPFC (KW $=7.477, p=0.0057$; Fig. 2). Compared to control subjects $(38.23 \pm 3.35$ million neurons; $\mathrm{CV}=0.154)$, IV SIV-infected subjects had a $49.5 \%$ neuronal reduction $(23.06 \pm 2.18$ million neurons; $\mathrm{CV}=0.175 ; p=0.0286)$, and PO SIV-infected subjects had a $52.8 \%$ neuronal reduction $(22.26 \pm 1.54$ million neurons; $\mathrm{CV}=0.154 ; p=0.016$ ). There was no statistical difference in neuronal populations between IV and PO SIV-infected subjects $(p=0.393)$. The average $\mathrm{CE}$ was below 0.05 . The decrease in neuronal populations in the dlPFC was correlated with viremia AUC (Fig. 3).

The estimated volume of the dIPFC was similar between groups (control $237.4 \pm 2.1 \mathrm{~mm}^{3}, \mathrm{CV}=0.1806$, and average $\mathrm{CE}=0.006 ; \mathrm{IV} 165.8 \pm 1.7 \mathrm{~mm}^{3}, \mathrm{CV}=0.1752$, and average $\mathrm{CE}=0.005 ; \mathrm{PO} 189.4 \pm 1.7 \mathrm{~mm}^{3}, \mathrm{CV}=0.1975$ and average $\mathrm{CE}=0.007 ; \mathrm{KW}=3.958, p=0.093$; Fig. 2). To determine average neuronal soma volume, a minimum of 400 neurons per subject were sampled. Neuronal soma volume did not differ between groups (KW=1.985, $p=0.269$; Fig. 2). The average $\mathrm{CE}$ was below 0.05 for both regional and neuronal volumes. Consistent with similar neuronal size and volumes between the groups, there was no correlation between viremia and neuronal size or volume. A consistent observation with each of the SIV + subjects was numerous cytoplasmic inclusions of neurons within the genu, dorsal, and ventral banks of the principle sulcus indicative of neurons in the process of dying (Fig. 2). Neurons within this region display pyknotic nuclei with adjacent clear spaces with basophilic structures outlining clear vacuoles (Christopher et al. 2017; Greaves 2007; Little et al. 1974). Within this same region, there was also positive immunostaining for p27 (Fig. 4).

\section{Discussion}

We have previously reported a significant reduction of hippocampal neuronal populations in both PO and IV SIVinfected subjects (Carryl et al. 2017; Curtis et al. 2014). The hippocampus is critical in learning and memory, but it is a particularly vulnerable region to intrusions throughout the lifespan (Bartsch and Wulff 2015). Hippocampal neurons are susceptible to Tat-mediated excitotoxicity (Campbell et al. 2011) and have been shown to be a vulnerable region in both adult and developmental models of HIV toxicity (Carryl et al. 2015). Given its susceptibility, the hippocampus was a logical starting point to assess the neurological impact of SIV on the developing brain (Carryl et al. 2015, 2017), although clinical evidence suggests disruptions throughout the cognitive circuitry (Boivin et al. 2018; Boivin et al. 2019; Cohen et al. 2015; Nichols et al. 2015; Nichols et al. 2016; Phillips et al. 2016; Van den Hof et al. 2019b; Van den Hof et al. 2020). Here, we expanded on our previous results to show that the dIPFC is vulnerable to the deleterious effects of post-natal SIV-infection.

The developing brain undergoes rapid development and reorganization beginning in the early fetal period through the second year of life (Kostovic and Rakic, 1980) with the pattern and tempo being remarkably similar between human and non-human primates (Huttenlocher 1990; Huttenlocher and Dabholkar 1997; Huttenlocher et al. 1982; Kostovic et al. 2019; Rakic 1978). This is especially true for the dlPFC which is a functionally advanced region of the brain that is responsible for attention, planning, executive function, decision-making, and mediating working memory (Beveridge et al. 2014; Fuster 2002; Goldman-Rakic 1987; Levy and Goldman-Rakic 1999). The dlPFC is one of the final regions of the cortex to fully develop, both functionally and structurally, and it continues developing throughout young adulthood (Beveridge et al. 2014). In both species, the period of rapid neurogenesis and neuronal migration is concentrated during the first two trimesters (Kostovic et al. 2019; Rakic 1978). The third trimester through early infancy marks a period of rapid maturation of the dlPFC whereby disruption of the developmental process may result in long-term neurological consequences (Spencer-Smith and 

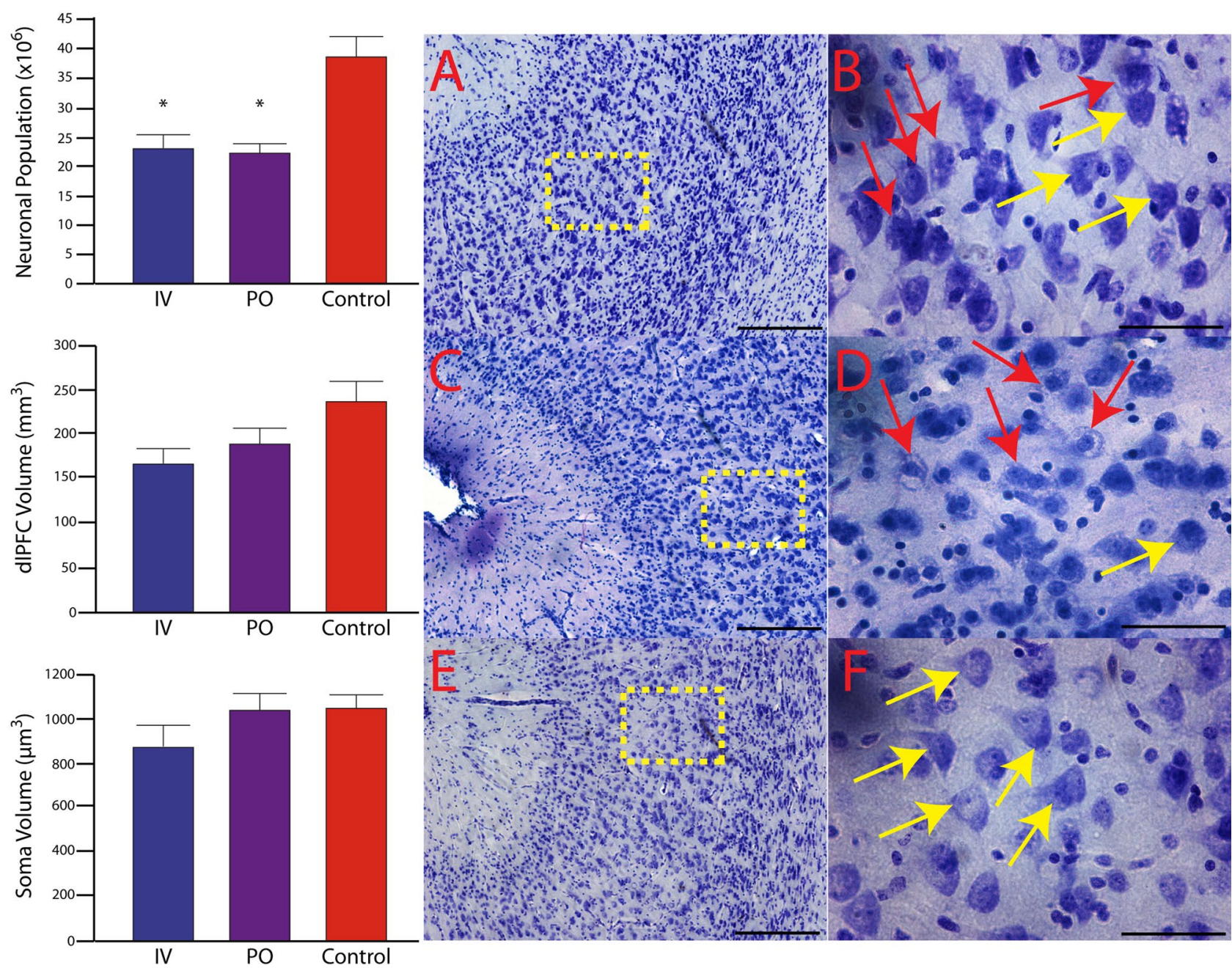

Fig. 2 There were significant neuronal reductions within the dlPFC of SIV-infected subjects compared to the control group. Overall dlPFC regional volume and neuronal soma volume were not different between groups. ${ }^{*} p<0.05$, one-tailed IV vs control and PO; twotailed PO vs control. In addition to the reduced neuronal populations, there is evidence of ongoing neuronal death in both the IV- $(\mathbf{A}, \mathbf{B})$ and PO-infected (C, D) groups centered around the genu and extending into the dorsal and ventral banks of the principle sulcus and mostly absent in control (E, F) subjects. Red arrows in $\mathbf{B}$ and $\mathbf{D}$ indicate neurons with pyknotic nuclei and vacuoles indicative of neurons in the process of dying. Yellow arrows in the IV- (B), PO (D), and control (F) groups indicate healthy-looking neurons. Yellow dashed boxes in panels $\mathbf{A}, \mathbf{C}$, and $\mathbf{E}$ indicate approximate area where highermagnification images were taken. Images $\mathbf{A}, \mathbf{C}$, and $\mathbf{E}$ were taken at $10 \times$, scale bar $=250 \mu \mathrm{m}$, and $\mathbf{B}, \mathbf{D}$, and $\mathbf{F}$ were taken at $63 \times$, scale $\mathrm{bar}=50 \mu \mathrm{m}$
Anderson 2009). A critical component of cortical network and functional maturation is synaptogenesis. Within the human dlPFC, the rapid phase of synaptogenesis begins during the third trimester of pregnancy continuing through the first 15 postnatal months (Huttenlocher and Dabholkar 1997). There is a plateau of synaptic densities from around 1-10 years old, followed by synaptic elimination during late childhood and adolescence. The time course of synaptogenesis resembles dendritic development and myelination. Similarly, in non-human primates, there is a rapid synaptogenesis phase in the dIPFC beginning during the last 2 months of pregnancy lasting through the first 2 postnatal months. After that, there is a constant synaptic density lasting through 3 years of age, followed by a steady decline from 3 to 20 years of age (Bourgeois et al. 1994).

In the current study, subjects were infected either during the neonatal or early infancy period concurrent with rapid synaptogenesis and maturation resulting in a significant reduction in neurons in the dIPFC. We found evidence of neurons with cytoplasmic inclusions and vacuoles indicative of actively dying cells confined primarily to the genu and extending into the dorsal and ventral banks of the principle sulcus. Although it is known that HIV and SIV induce neuronal death (Beck et al. 2015; Kaul 2008; Kaul et al. 2001), the clustering of apparently dying neurons within the genu region in close proximity to $\mathrm{p} 27$ immunoreactivity, was not 


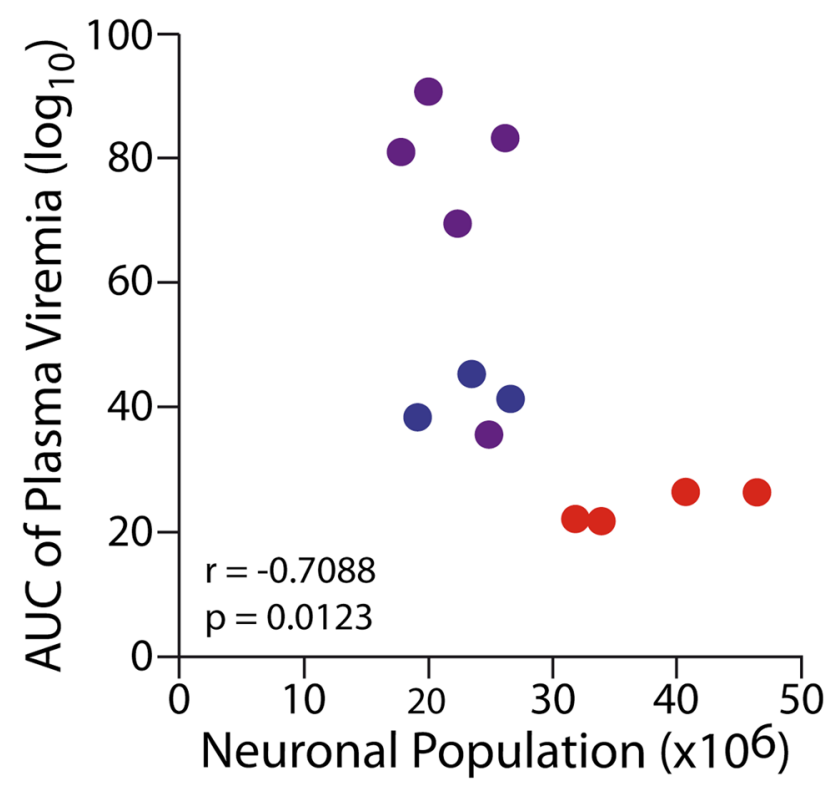

Fig. 3 AUC analysis indicates a significant negative correlation between plasma viremia and neuronal population in the dIPFC

observed on the upper or lower lips of the principle sulcus or in the hippocampus (Carryl et al. 2017), indicating that this region may be particularly vulnerable. Apoptosis and inflammation along with autophagy are probable causes of HIV/ SIV-associated neuronal death (Saylor et al. 2016; Zhou et al. 2011). During apoptosis, cells initiate an innate suicide program that results in self-destruction either through phagocyte recruitment and/or their enveloping (Perez-Garijo et al. 2013). Apoptosis leads to altered morphology of a cell, with the cytoplasm appearing denser and more contained. One of the morphological indicators of apoptosis is pyknosisthe process of chromatin condensation (Elmore 2007; Voss and Strasser 2020), which we observed within the genu of the principle sulcus corresponding to area 46 of the dlPFC. The HIV envelop glycoprotein (gp120) and transactivator of transcription (Tat) have been shown to directly induce neuronal apoptosis (Bagashev and Sawaya 2013; Kaul 2008) and may contribute to the neuronal loss in the dlPFC. Additionally, microglia and astrocytes (which are suspected of harboring the latent HIV reservoir) are capable of productive HIV infection and play a significant role in the indirect inflammatory neurotoxic cascade of HIV (Bozzelli et al. 2019; Li et al. 2020; Mocchetti et al. 2013; Pandey and Seth 2019). However, pediatric SIV infection may affect the dIPFC beyond neuronal death. Given that this developmental time point corresponds to rapid synaptogenesis and dendritic lengthening, it is conceivable that this process is compromised. In addition to inducing neuronal death, HIV has also been shown to affect synaptic levels and is implicated as a mechanism of cognitive dysfunction in adult HIV/ SIV (Gupta et al. 2010; Wenzel et al. 2019). In fact, the HIV protein gp120 has been shown to reduce dendritic length (Avdoshina et al. 2020) and induce neurite pruning (Speidell et al. 2019). Pediatric HIV may disrupt the neuron-microglia interaction, in a non-inflammatory manner, that affects the normal role that microglia play in selective synapse elimination which is critical for maturation and network development (Paolicelli et al. 2011; Paolicelli and Ferretti 2017; Paolicelli and Gross 2011). During development, neurons upregulate the release of CXCL1 (fractalkine) that bind to the receptor CXCR1 expressed on microglia, leading to

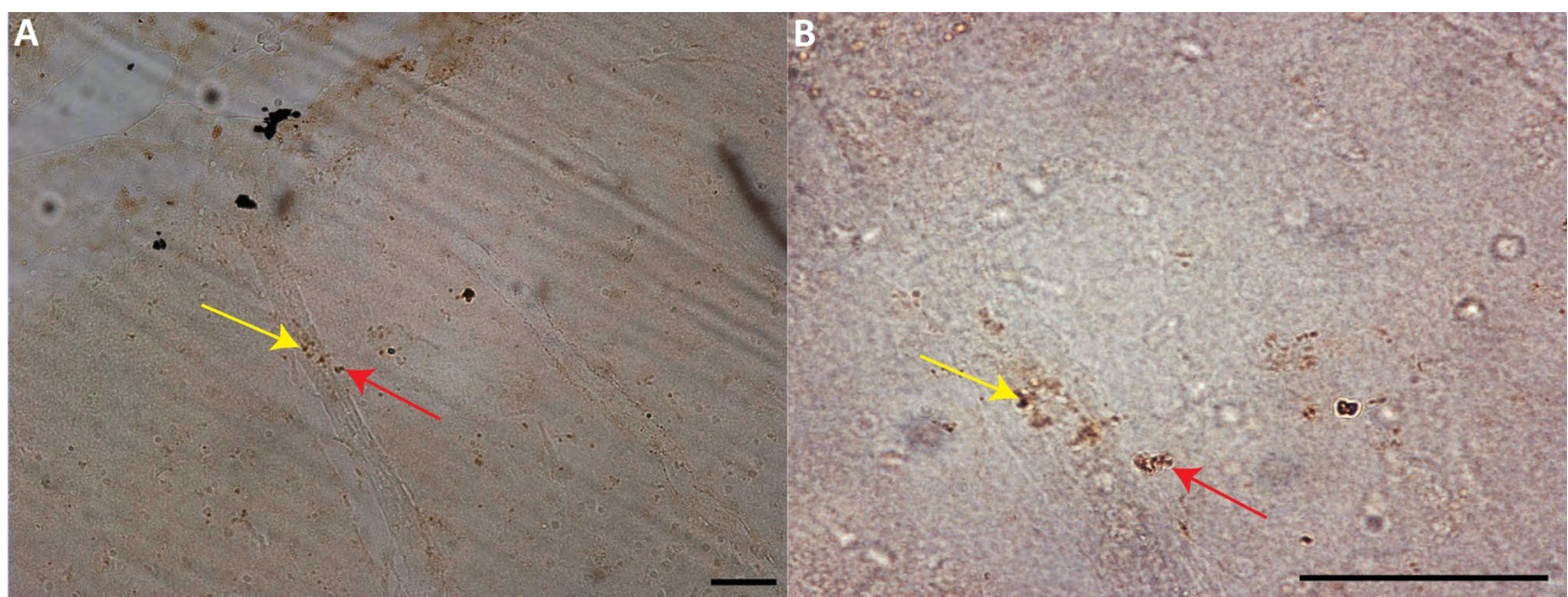

Fig. 4 Immunohistochemical analysis demonstrates p27-positive staining throughout the dlPFC and adjacent pia matter. In panel A, the yellow arrow indicates a blood vessel with p27-positive staining inside the vessel and the red arrow p-27 outside the vessel within the brain parenchyma. In panel $\mathbf{B}$, the red arrow shows the perivascular p27 location. Panel A was taken at $20 \times$, and $\mathbf{B}$ was taken at $63 \times$, scale bar $=50 \mu \mathrm{m}$ 
synaptic pruning and strengthening of the neuronal electrophysiological properties (Paolicelli and Ferretti 2017). However, the HIV protein Tat reduces CX3CR1 expression compromising the ability of microglia to guide the maturation process (Duan et al. 2014) potentially leading to an excess of weak synapses affecting the foundation of the developing neural network (Paolicelli et al. 2011; Paolicelli and Ferretti 2017; Paolicelli and Gross 2011). Likewise, astrocytes actively promote synaptogenesis, post-synaptic receptor clustering, and dendritic arborization (Li et al. 2020; Shan et al. 2021). Astrocyte dysfunction, as a result of HIV infection, is associated with compromised blood-brain barrier integrity, neuronal survival as well affecting synapses through a Tat-mediated release of extracellular vesicle microRNA-7 leading to reduced synaptic densities by downregulating neuroligin-2 in neurons (Hu et al. 2020; Ton and Xiong 2013). Altered neuronal morphology and synaptogenesis and the roles of microglia and astrocytes during this critical period warrant further investigation within this model as it could further affect cortical maturation with long-lasting consequences especially in cognitive and executive domains (Spencer-Smith and Anderson 2009). The lack of differences in neuronal populations between the IV- or PO-infected groups further suggests that post-natal period is vulnerable period for the neurotoxic effects of HIV infection. This conclusion is further suggested by the finding that even the animal with the lowest plasma viral load at euthanasia displayed neuronal loss. To account for the overall SIV replication, we calculated the AUC of viremia over time. AUC viremia was negatively correlated with neuronal populations in the dIPFC, whereas, in the same subjects, the hippocampal neuronal loss was not associated with plasma viral load (Carryl et al. 2017). The current study suggests a regional variation that may correlate with clinical data suggesting poorer neurocognitive outcomes with higher viral load in pHIV within the first 3 years of life (Weber et al. 2017). Future studies need to determine if SIV present in the brain or SIV-induced inflammation is the primary driver of neuronal death.

The role of the dIPFC and its relationship to the deficits seen in pediatric HIV have its roots in its functional connectivity. The dIPFC which encompasses the superior and middle frontal gyri (areas 9 and 46) in humans and the principle sulcus including the dorsal and ventral banks in nonhuman primates has extensive cortico-cortical connections (Petrides and Pandya 1999). Tracing studies in non-human primates shows extensive connections with multimodal, motor, and paralimbic regions. Within the motor domain, the dIPFC is reciprocally connected with the supplementary motor area and motor regions of the cingulate cortex to influence the initiation and execution of skilled movements (Bates and Goldman-Rakic 1993; Lu et al. 1994). Multimodal temporal cortical areas along with paralimbic cortical areas (cingulate, retrosplenial, and rostral temporal cortex) share reciprocal connections with the dIPFC providing a functional link between the dIPFC and hippocampus along with playing a role in spatial cognition (Mitchell et al. 2018; Morris et al. 1999; Petrides and Pandya 1999).

Well-documented studies have demonstrated the significant roles of various brain regions in executive and cognitive function such as the hippocampus and dIPFC. Executive function can be described as the assemblance of cognitive processes that are needed to successfully commence, track, and manage actions and thoughts (Walker and Brown 2018). In child development, executive function plays a critical role in various areas such as moral and communicative behavior, and social cognition (Kochanska et al. 1997; Moriguchi et al. 2010, 2008). Executive function can be divided into three main compartments: shifting, inhibition, and working memory (Moriguchi and Hiraki 2013). The dIPFC has consistently been identified as a region that plays a vital role in visuospatial working memory in adolescents, adults, and non-human primates (Braver et al, 1997; Casey et al. 2005; Goldman-Rakic 1995a, b, 1996). The consistently reported neuropsychological findings of deficits of cognition and executive function in pHIV-infected children (Boivin et al. 2018; Boivin et al. 2019; Boivin et al. 1995; Cohen et al. 2015; Coutifaris et al. 2020; Nichols et al. 2015; Phillips et al. 2016; Van den Hof et al. 2019b; Van den Hof et al. 2020; Willen et al. 2017) strongly implicate dysfunction of the dlPFC network. Data presented here provide the anatomical basis of neuronal loss that may, in part, underlie the cognitive and executive dysfunction in pHIV infection. It should be noted, however, that the subjects in this study are ART-naïve and while most HIV + children in resource-rich countries have access to ART, neurocognitive deficits persist (van Arnhem et al. 2013). Thus, future studies investigating the effects of ART on brain development of SIV-infected infant macaques are warranted.

\section{Conclusion}

The findings of this study are significant due to the clinical implications in pHIV-infected children as they move through adolescence and adulthood. The long-term neuropsychological deficits in pHIV may impact academic performance and self-management permeating all facets of life, necessitating early intervention strategies aimed at minimizing the neurodevelopmental impact (Mofenson and Cotton 2013; Sirois et al. 2016). Here, we describe neuronal loss in the dlPFC which may, in part, underlie the executive dysfunction reported in pHIV infection. Since executive and cognitive function relies on multiple regions as part of a network, our data do not preclude vulnerabilities in regions outside of the hippocampus and dlPFC. Given 
that psychiatric disorders are reported in vertically infected adolescents, it is quite possible that deficits in limbic-related regions begin early in the pathogenesis of pHIV infection. pHIV adolescents are more susceptible to neurocognitive deficits (Bisiacchi et al. 2000; Foster et al. 2012; Jeremy et al. 2005; Kapetanovic et al. 2010; Laughton et al. 2013; Smith et al. 2006; Walker et al. 2013) and depression (Gadow et al. 2012) than HIV + adults that contribute to lower self-esteem and poor adherence to medication (Hazra et al. 2010; MacDonell et al. 2013; Sohn and Hazra. 2013). Youth have the most to gain from an intervention that would improve self-management of HIV, because they have the longest life-years to live with the disease and are at high risk for transmission. Neurocognitive impairment in pHIV infection is associated with a greater risk for disease progression and poorer morbidity even in the advent of antiretroviral therapy (Pearson et al. 2000).

Funding Research reported in this publication was supported by the Office of The Director, National Institutes of Health under Award Number P51OD011107. This publication resulted (in part) from research supported by R03MH107261, the National Institute on Minority Health and Health Disparities of the National Institutes of Health under Award Number 2U54MD007597, and the District of Columbia Center for AIDS Research (to MWB), an NIH funded program (P30AI117970), which is supported by the following NIH Co-funding and Participating Institutes and Centers: NIAID, NCI, NICHD, NHLBI, NIDA, NIMH, NIA, NIDDK, NIMHD, NIDCR, NINR, FIC and OAR; 1R01DE019064 (NIH/NIDCR) and 1R01DE022285 (NIH/ NIDCR) to K.D.P.; N.A. received Saudi Arabia Government Graduate Student Support. JB received support from the Howard University National Science Foundation (1809086) LSAMP program. The content is solely the responsibility of the authors and does not necessarily represent the official views of the NIH. The following reagent was obtained through the NIH HIV Reagent Program, Division of AIDS, NIAID, NIH: anti-simian immunodeficiency virus (SIV) SIVmac p27 monoclonal (55-2F12), ARP-1610, contributed by Dr, Niels Pedersen. We thank Dr. Marjorie Gondre-Lewis, Howard University, for the use of her Stereology system.

\section{Declarations}

Conflict of interest The authors declare no competing interests.

Open Access This article is licensed under a Creative Commons Attribution 4.0 International License, which permits use, sharing, adaptation, distribution and reproduction in any medium or format, as long as you give appropriate credit to the original author(s) and the source, provide a link to the Creative Commons licence, and indicate if changes were made. The images or other third party material in this article are included in the article's Creative Commons licence, unless indicated otherwise in a credit line to the material. If material is not included in the article's Creative Commons licence and your intended use is not permitted by statutory regulation or exceeds the permitted use, you will need to obtain permission directly from the copyright holder. To view a copy of this licence, visit http://creativecommons.org/licenses/by/4.0/.

\section{References}

BrainMaps: An interactive multiresolution brain atlas

Abel K (2009) The rhesus macaque pediatric SIV infection model-a valuable tool in understanding infant HIV-1 pathogenesis and for designing pediatric HIV-1 prevention strategies. Curr HIV Res 7:2-11

Ackermann C, Andronikou S, Laughton B, Kidd M, Dobbels E, Innes S, van Toorn R, Cotton M (2014) White matter signal abnormalities in children with suspected HIV-related neurologic disease on early combination antiretroviral therapy. Pediatr Infect Dis J 33:e207-e212

Ackermann C, Andronikou S, Saleh MG, Laughton B, Alhamud AA, van der Kouwe A, Kidd M, Cotton MF, Meintjes EM (2016) Early antiretroviral therapy in HIV-infected children is associated with diffuse white matter structural abnormality and corpus callosum sparing. AJNR Am J Neuroradiol 37:2363-2369

Ackermann C, van Toorn R, Andronikou S (2019) Human immunodeficiency virus-related cerebral white matter disease in children. Pediatr Radiol 49:652-662

Amedee AM, Phillips B, Jensen K, Robichaux S, Lacour N, Burke M, Piatak M Jr, Lifson JD, Kozlowski PA, Van Rompay KKA, De Paris K (2018) Early sites of virus replication after oral SIVmac251 infection of infant macaques: implications for pathogenesis. AIDS Res Hum Retroviruses 34:286-299

Avdoshina V, Mahoney M, Gilmore SF, Wenzel ED, Anderson A, Letendre SL, Imamichi T, Fischer NO, Mocchetti I (2020) HIV influences microtubule associated protein-2: potential marker of HIV-associated neurocognitive disorders. AIDS 34:979-988

Bagashev A, Sawaya BE (2013) Roles and functions of HIV-1 Tat protein in the CNS: an overview. Virol J 10:358

Bartsch T, Wulff P (2015) The hippocampus in aging and disease: from plasticity to vulnerability. Neuroscience 309:1-16

Bates JF, Goldman-Rakic PS (1993) Prefrontal connections of medial motor areas in the rhesus monkey. J Comp Neurol 336:211-228

Beck SE, Queen SE, Witwer KW, Metcalf Pate KA, Mangus LM, Gama L, Adams RJ, Clements JE, Christine Zink M, Mankowski JL (2015) Paving the path to HIV neurotherapy: predicting SIV CNS disease. Eur J Pharmacol 759:303-312

Becquet R, Ekouevi DK, Arrive E, Stringer JS, Meda N, Chaix ML, Treluyer JM, Leroy V, Rouzioux C, Blanche S, Dabis F (2009) Universal antiretroviral therapy for pregnant and breast-feeding HIV-1-infected women: towards the elimination of mother-tochild transmission of HIV-1 in resource-limited settings. Clin Infect Dis 49:1936-1945

Becquet R, Ekouevi DK, Menan H, Amani-Bosse C, Bequet L, Viho I, Dabis F, Timite-Konan M, Leroy V, Group ADPS (2008) Early mixed feeding and breastfeeding beyond 6 months increase the risk of postnatal HIV transmission: ANRS 1201/1202 Ditrame Plus, Abidjan, Cote d'Ivoire. Prev Med 47:27-33

Beveridge NJ, Santarelli DM, Wang X, Tooney PA, Webster MJ, Weickert CS, Cairns MJ (2014) Maturation of the human dorsolateral prefrontal cortex coincides with a dynamic shift in microRNA expression. Schizophr Bull 40:399-409

Bisiacchi PS, Suppiej A, Laverda A (2000) Neuropsychological evaluation of neurologically asymptomatic HIV-infected children. Brain Cogn 43:49-52

Blokhuis C, Mutsaerts HJ, Cohen S, Scherpbier HJ, Caan MW, Majoie CB, Kuijpers TW, Reiss P, Wit FW, Pajkrt D (2017) Higher subcortical and white matter cerebral blood flow in perinatally HIVinfected children. Medicine (Baltimore) 96:e5891

Blumberg BM, Gelbard HA, Epstein LG (1994) HIV-1 infection of the developing nervous system: central role of astrocytes in pathogenesis. Virus Res 32:253-267 
Boivin MJ, Barlow-Mosha L, Chernoff MC, Laughton B, Zimmer B, Joyce C, Bwakura-Dangarembizi M, Ratswana M, Abrahams N, Fairlie L, Gous H, Kamthunzi P, McCarthy K, Familiar-Lopez I, JeanPhillippe P, Coetzee J, Violari A, Cotton MF, Palumbo PE (2018) Neuropsychological performance in African children with HIV enrolled in a multisite antiretroviral clinical trial. AIDS 32:189-204

Boivin MJ, Chernoff M, Fairlie L, Laughton B, Zimmer B, Joyce C, Barlow-Mosha L, Bwakura-Dangarembizi M, Vhembo T, Ratswana M, Kamthunzi P, McCarthy K, Familiar-Lopez I, JeanPhilippe P, Coetzee J, Abrahams N, Gous H, Violari A, Cotton MF, Palumbo PE (2019) African multi-site 2-year neuropsychological study of school-age children perinatally infected, exposed, and unexposed to human immunodeficiency virus. Clin Infect Dis

Boivin MJ, Green SD, Davies AG, Giordani B, Mokili JK, Cutting WA (1995) A preliminary evaluation of the cognitive and motor effects of pediatric HIV infection in Zairian children. Health Psychol 14:13-21

Bourgeois JP, Goldman-Rakic PS, Rakic P (1994) Synaptogenesis in the prefrontal cortex of rhesus monkeys. Cereb Cortex 4:78-96

Bozzelli PL, Yin T, Avdoshina V, Mocchetti I, Conant KE, Maguire-Zeiss KA (2019) HIV-1 Tat promotes astrocytic release of CCL2 through MMP/PAR-1 signaling. Glia 67:1719-1729

Brady MT, Oleske JM, Williams PL, Elgie C, Mofenson LM, Dankner WM, Van Dyke RB, Pediatric ACTGCT (2010) Declines in mortality rates and changes in causes of death in HIV-1-infected children during the HAART era. J Acquir Immune Defic Syndr 53:86-94

Braver TS, Cohen JD, Nystrom LE, Jonides J, Smith EE, Noll DC (1997) A parametric study of prefrontal cortex involvement in human working memory. Neuroimage 5:49-62

Burke M, Zangenehpour S, Mouton PR, Ptito M (2009a) Knowing what counts: unbiased stereology in the non-human primate brain. J Vis Exp

Burke MW, Zangenehpour S, Ptito M (2009b) Brain banking: making the most of your research specimens. J Vis Exp

Campbell GR, Watkins JD, Loret EP, Spector SA (2011) Differential induction of rat neuronal excitotoxic cell death by human immunodeficiency virus type 1 clade $B$ and $C$ tat proteins. AIDS Res Hum Retroviruses 27:647-654

Carryl H, Swang M, Lawrence J, Curtis K, Kamboj H, Van Rompay KK, De Paris K, Burke MW (2015) Of mice and monkeys: can animal models be utilized to study neurological consequences of pediatric HIV-1 infection? ACS Chem Neurosci 6:1276-1289

Carryl H, Van Rompay KK, De Paris K, Burke MW (2017) Hippocampal neuronal loss in infant macaques orally infected with virulent simian immunodeficiency virus (SIV). Brain Sci 7

Casey BJ, Tottenham N, Liston C, Durston S (2005) Imaging the developing brain: what have we learned about cognitive development? Trends Cogn Sci 9:104-110

Christopher MA, Myrick DA, Barwick BG, Engstrom AK, PorterStransky KA, Boss JM, Weinshenker D, Levey AI, Katz DJ (2017) LSD1 protects against hippocampal and cortical neurodegeneration. Nat Commun 8:805

Clancy B, Darlington RB, Finlay BL (2001) Translating developmental time across mammalian species. Neuroscience 105:7-17

Cline AN, Bess JW, Piatak M Jr, Lifson JD (2005) Highly sensitive SIV plasma viral load assay: practical considerations, realistic performance expectations, and application to reverse engineering of vaccines for AIDS. J Med Primatol 34:303-312

Cohen S, Caan MW, Mutsaerts HJ, Scherpbier HJ, Kuijpers TW, Reiss P, Majoie CB, Pajkrt D (2016) Cerebral injury in perinatally HIV-infected children compared to matched healthy controls. Neurology 86:19-27
Cohen S, Ter Stege JA, Geurtsen GJ, Scherpbier HJ, Kuijpers TW, Reiss P, Schmand B, Pajkrt D (2015) Poorer cognitive performance in perinatally HIV-infected children versus healthy socioeconomically matched controls. Clin Infect Dis 60:1111-1119

Coutifaris P, Byrd D, Childs J, Clark U, Posada R, Robbins R, Morgello $S$ (2020) Neurobehavioral outcomes in young adults with perinatally-acquired HIV. Aids

Curtis K, Rollins M, Carryl H, Bradshaw K, Van Rompay KK, Abel K, Burke MW (2014) Reduction of pyramidal and immature hippocampal neurons in pediatric simian immunodeficiency virus infection. NeuroReport 25:973-978

Dean O, Buda A, Adams HR, Mwanza-Kabaghe S, Potchen MJ, Mbewe EG, Kabundula PP, Moghaddam SM, Birbeck GL, Bearden DR (2020) Brain magnetic resonance imaging findings associated with cognitive impairment in children and adolescents with human immunodeficiency virus in Zambia. Pediatr Neurol 102:28-35

Donald KA, Walker KG, Kilborn T, Carrara H, Langerak NG, Eley B, Wilmshurst JM (2015) HIV Encephalopathy: pediatric case series description and insights from the clinic coalface. AIDS Res Ther 12:2

Dowshen N, D'Angelo L (2011) Health care transition for youth living with HIV/AIDS. Pediatrics 128:762-771

Duan M, Yao H, Cai Y, Liao K, Seth P, Buch S (2014) HIV-1 Tat disrupts CX3CL1-CX3CR1 axis in microglia via the NFkappaBYY1 pathway. Curr HIV Res 12:189-200

Elmore S (2007) Apoptosis: a review of programmed cell death. Toxicol Pathol 35:495-516

Foster SB, Lu M, Glaze DG, Reuben JM, Harris LL, Cohen EN, Lee BN, Zhao E, Paul ME, Schwarzwald H, McMullen-Jackson C, Clark C, Armstrong FD, Brouwers PY, Miller TL, Colin AA, Scott GB, Shahzeidi S, Willen EJ, Asthana D, Lipshultz SE, Thompson BW, Shearer WT (2012) Associations of cytokines, sleep patterns, and neurocognitive function in youth with HIV infection. Clin Immunol 144:13-23

Friedman HR, Goldman-Rakic PS (1988) Activation of the hippocampus and dentate gyrus by working-memory: a 2-deoxyglucose study of behaving rhesus monkeys. J Neurosci 8:4693-4706

Fuster JM (2002) Frontal lobe and cognitive development. J Neurocytol 31:373-385

Gadow KD, Angelidou K, Chernoff M, Williams PL, Heston J, Hodge J, Nachman S (2012) Longitudinal study of emerging mental health concerns in youth perinatally infected with HIV and peer comparisons. J Dev Behav Pediatr 33:456-468

Gelbard HA, James HJ, Sharer LR, Perry SW, Saito Y, Kazee AM, Blumberg BM, Epstein LG (1995) Apoptotic neurons in brains from paediatric patients with HIV-1 encephalitis and progressive encephalopathy. Neuropathol Appl Neurobiol 21:208-217

Goldman-Rakic PS (1987) Development of cortical circuitry and cognitive function. Child Dev 58:601-622

Goldman-Rakic PS (1995a) Architecture of the prefrontal cortex and the central executive. Ann N Y Acad Sci 769:71-83

Goldman-Rakic PS (1995b) Cellular basis of working memory. Neuron 14:477-485

Goldman-Rakic PS (1996) The prefrontal landscape: implications of functional architecture for understanding human mentation and the central executive. Philos Trans R Soc Lond B Biol Sci $351: 1445-1453$

Greaves P (2007) Histopathology of preclinical toxicity studies, Third edn. Elsivier Sci

Gupta RG, Kelly KM, Helke KL, Queen SE, Karper JM, Dorsey JL, Brice AK, Adams RJ, Tarwater PM, Kolson DL, Mankowski JL (2010) HIV and SIV induce alterations in CNS CaMKII expression and activation: a potential mechanism for cognitive impairment. Am J Pathol 176:2776-2784 
Hazra R, Siberry GK, Mofenson LM (2010) Growing up with HIV: children, adolescents, and young adults with perinatally acquired HIV infection. Annu Rev Med 61:169-185

Herting MM, Uban KA, Williams PL, Gautam P, Huo Y, Malee K, Yogev R, Csernansky J, Wang L, Nichols S, Van Dyke R, Sowell ER (2015) Default mode connectivity in youth with perinatally acquired HIV. Medicine (Baltimore) 94:e1417

Higgins JR, Sutjipto S, Marx PA, Pedersen NC (1992) Shared antigenic epitopes of the major core proteins of human and simian immunodeficiency virus isolates. J Med Primatol 21:265-269

Hoare J, Fouche JP, Phillips N, Joska JA, Donald KA, Thomas K, Stein DJ (2015a) Clinical associations of white matter damage in cART-treated HIV-positive children in South Africa. J Neurovirol 21:120-128

Hoare J, Fouche JP, Phillips N, Joska JA, Paul R, Donald KA, Thomas KG, Stein DJ (2015b) White matter micro-structural changes in ART-naive and ART-treated children and adolescents infected with HIV in South Africa. AIDS 29:1793-1801

Hoare J, Fouche JP, Spottiswoode B, Donald K, Philipps N, Bezuidenhout $\mathrm{H}$, Mulligan C, Webster V, Oduro C, Schrieff L, Paul R, Zar H, Thomas K, Stein D (2012a) A diffusion tensor imaging and neurocognitive study of HIV-positive children who are HAARTnaïve "slow progressors." J Neurovirol 18:205-212

Hoare J, Myer L, Heany S, Fouche JP, Phillips N, Zar HJ, Stein DJ (2020) Cognition, structural brain changes, and systemic inflammation in adolescents living with HIV on antiretroviral therapy. J Acquir Immune Defic Syndr 84:114-121

Hoare J, Westgarth-Taylor J, Fouche JP, Spottiswoode B, Paul R, Thomas K, Stein D, Joska J (2012b) A diffusion tensor imaging and neuropsychological study of prospective memory impairment in South African HIV positive individuals. Metab Brain Dis 27:289-297

Hu G, Niu F, Liao K, Periyasamy P, Sil S, Liu J, Dravid SM, Buch S (2020) HIV-1 Tat-induced astrocytic extracellular vesicle miR-7 impairs synaptic architecture. J Neuroimmune Pharmacol 15:538-553

Huttenlocher PR (1990) Morphometric study of human cerebral cortex development. Neuropsychologia 28:517-527

Huttenlocher PR, Dabholkar AS (1997) Regional differences in synaptogenesis in human cerebral cortex. J Comp Neurol 387:167-178

Huttenlocher PR, De Courten C, Garey LJ, Van der Loos H (1982) Synaptic development in human cerebral cortex. Int J Neurol 16-17:144-154

Jensen K, Dela Pena-Ponce MG, Piatak M, Jr., Shoemaker R, Oswald K, Jacobs WR, Jr., Fennelly G, Lucero C, Mollan KR, Hudgens MG, Amedee A, Kozlowski PA, Estes JD, Lifson JD, Van Rompay KK, Larsen M, De Paris K (2017) Balancing trained immunity with persistent immune activation and the risk of simian immunodeficiency virus infection in infant macaques vaccinated with attenuated Mycobacterium tuberculosis or Mycobacterium bovis BCG vaccine. Clin Vaccine Immunol 24

Jensen K, Nabi R, Van Rompay KK, Robichaux S, Lifson JD, Piatak M Jr, Jacobs WR Jr, Fennelly G, Canfield D, Mollan KR, Hudgens MG, Larsen MH, Amedee AM, Kozlowski PA, De Paris K (2016) Vaccine-elicited mucosal and systemic antibody responses are associated with reduced simian immunodeficiency viremia in infant rhesus macaques. J Virol 90:7285-7302

Jensen K, Pena MG, Wilson RL, Ranganathan UD, Jacobs WR Jr, Fennelly G, Larsen M, Van Rompay KK, Kozlowski PA, Abel K (2013) A neonatal oral Mycobacterium tuberculosis-SIV prime/ intramuscular MVA-SIV boost combination vaccine induces both SIV and Mtb-specific immune responses in infant macaques. Trials Vaccinol 2:53-63

Jensen K, Ranganathan UD, Van Rompay KK, Canfield DR, Khan I, Ravindran R, Luciw PA, Jacobs WR Jr, Fennelly G, Larsen MH, Abel K (2012) A recombinant attenuated Mycobacterium tuberculosis vaccine strain is safe in immunosuppressed simian immunodeficiency virus-infected infant macaques. Clin Vaccine Immunol 19:1170-1181

Jeremy RJ, Kim S, Nozyce M, Nachman S, McIntosh K, Pelton SI, Yogev R, Wiznia A, Johnson GM, Krogstad P, Stanley K (2005) Neuropsychological functioning and viral load in stable antiretroviral therapy-experienced HIV-infected children. Pediatrics $115: 380-387$

Joelving FC, Billeskov R, Christensen JR, West M, Pakkenberg B (2006) Hippocampal neuron and glial cell numbers in Parkinson's disease-a stereological study. Hippocampus 16:826-833

Kapetanovic S, Leister E, Nichols S, Miller T, Tassiopoulos K, Hazra R, Gelbard HA, Malee KM, Kammerer B, Mendez AJ, Williams PL (2010) Relationships between markers of vascular dysfunction and neurodevelopmental outcomes in perinatally HIVinfected youth. AIDS 24:1481-1491

Kaul M (2008) HIV's double strike at the brain: neuronal toxicity and compromised neurogenesis. Front Biosci 13:2484-2494

Kaul M, Garden GA, Lipton SA (2001) Pathways to neuronal injury and apoptosis in HIV-associated dementia. Nature 410:988-994

Kochanska G, Murray K, Coy KC (1997) Inhibitory control as a contributor to conscience in childhood: from toddler to early school age. Child Dev 68:263-277

Kostovic I, Rakic P (1980) Cytology and time of origin of interstitial neurons in the white matter in infant and adult human and monkey telencephalon. J Neurocytol 9:219-242

Kostovic I, Sedmak G, Judas M (2019) Neural histology and neurogenesis of the human fetal and infant brain. Neuroimage 188:743-773

Laughton B, Cornell M, Boivin M, Van Rie A (2013) Neurodevelopment in perinatally HIV-infected children: a concern for adolescence. J Int AIDS Soc 16:18603

Levy R, Goldman-Rakic PS (1999) Association of storage and processing functions in the dorsolateral prefrontal cortex of the nonhuman primate. J Neurosci 19:5149-5158

Lewis-de Los Angeles CP, Williams PL, Huo Y, Wang SD, Uban KA, Herting MM, Malee K, Yogev R, Csernansky JG, Nichols S, Van Dyke RB, Sowell ER, Wang L (2017) Lower total and regional grey matter brain volumes in youth with perinatally-acquired HIV infection: associations with HIV disease severity, substance use, and cognition. Brain Behav Immun 62:100-109

Li GH, Maric D, Major EO, Nath A (2020) Productive HIV infection in astrocytes can be established via a nonclassical mechanism. AIDS 34:963-978

Lisman J, Buzsaki G, Eichenbaum H, Nadel L, Ranganath C, Redish AD (2017) Viewpoints: how the hippocampus contributes to memory, navigation and cognition. Nat Neurosci 20:1434-1447

Little JR, Sundt TM Jr, Kerr FW (1974) Neuronal alterations in developing cortical infarction. An experimental study in monkeys. J Neurosurg 40:186-198

Lu MT, Preston JB, Strick PL (1994) Interconnections between the prefrontal cortex and the premotor areas in the frontal lobe. $\mathrm{J}$ Comp Neurol 341:375-392

MacDonell K, Naar-King S, Huszti H, Belzer M (2013) Barriers to medication adherence in behaviorally and perinatally infected youth living with HIV. AIDS Behav 17:86-93

McCarthy G, Puce A, Constable RT, Krystal JH, Gore JC, GoldmanRakic P (1996) Activation of human prefrontal cortex during spatial and nonspatial working memory tasks measured by functional MRI. Cereb Cortex 6:600-611

McLaurin KA, Booze RM, Mactutus CF (2017a) Selective developmental alterations in the HIV-1 transgenic rat: opportunities for diagnosis of pediatric HIV-1. J Neurovirol 23:87-98

McLaurin KA, Booze RM, Mactutus CF (2017b) Temporal processsing demands in the HIV-1 transgenic rat: amodal gating and implications for diagnostics. Int J Dev Neurosci 57:12-20 
McLaurin KA, Cook AK, Li H, League AF, Mactutus CF, Booze RM (2018a) Synaptic connectivity in medium spiny neurons of the nucleus accumbens: a sex-dependent mechanism underlying apathy in the HIV-1 transgenic rat. Front Behav Neurosci 12:285

McLaurin KA, Li H, Booze RM, Fairchild AJ, Mactutus CF (2018b) Unraveling individual differences in the HIV-1 transgenic rat: therapeutic efficacy of methylphenidate. Sci Rep 8:136

McLaurin KA, Li H, Cook AK, Booze RM, Mactutus CF (2020) S-EQUOL: a neuroprotective therapeutic for chronic neurocognitive impairments in pediatric HIV. J Neurovirol 26:704-718

McLaurin KA, Moran LM, Li H, Booze RM, Mactutus CF (2017c) A gap in time: extending our knowledge of temporal processing deficits in the HIV-1 transgenic rat. J Neuroimmune Pharmacol 12:171-179

Mitchell AS, Czajkowski R, Zhang N, Jeffery K, Nelson AJD (2018) Retrosplenial cortex and its role in spatial cognition. Brain Neurosci Adv 2:2398212818757098

Mocchetti I, Campbell LA, Harry GJ, Avdoshina V (2013) When human immunodeficiency virus meets chemokines and microglia: neuroprotection or neurodegeneration? J Neuroimmune Pharmacol 8:118-131

Mofenson LM, Cotton MF (2013) The challenges of success: adolescents with perinatal HIV infection. J Int AIDS Soc 16:18650

Moran LM, Booze RM, Mactutus CF (2013) Time and time again: temporal processing demands implicate perceptual and gating deficits in the HIV-1 transgenic rat. J Neuroimmune Pharmacol 8:988-997

Moran LM, Booze RM, Mactutus CF (2014a) Modeling deficits in attention, inhibition, and flexibility in HAND. J Neuroimmune Pharmacol 9:508-521

Moran LM, Fitting S, Booze RM, Webb KM, Mactutus CF (2014b) Neonatal intrahippocampal HIV-1 protein Tat(1-86) injection: neurobehavioral alterations in the absence of increased inflammatory cytokine activation. Int J Dev Neurosci 38:195-203

Moran LM, McLaurin KA, Booze RM, Mactutus CF (2019) Neurorestoration of sustained attention in a model of HIV-1 associated neurocognitive disorders. Front Behav Neurosci 13:169

Moriguchi Y, Hiraki K (2013) Prefrontal cortex and executive function in young children: a review of NIRS studies. Front Hum Neurosci 7:867

Moriguchi Y, Kanda T, Ishiguro H, Itakura S (2010) Children perseverate to a human's actions but not to a robot's actions. Dev Sci 13:62-68

Moriguchi Y, Okanda M, Itakura S (2008) Young children's yes bias: how does it relate to verbal ability, inhibitory control, and theory of mind? First Lang 28:431-442

Morris R, Pandya DN, Petrides M (1999) Fiber system linking the mid-dorsolateral frontal cortex with the retrosplenial/presubicular region in the rhesus monkey. J Comp Neurol 407:183-192

Mouton PR, Pakkenberg B, Gundersen HJ, Price DL (1994) Absolute number and size of pigmented locus coeruleus neurons in young and aged individuals. J Chem Neuroanat 7:185-190

Musielak K, Fine J (2016) An updated systematic review of neuroimaging studies of children and adolescents with perinatally acquired HIV. Journal of Pediatric Neuropsychology 2:16

Nichols SL, Brummel SS, Smith RA, Garvie PA, Hunter SJ, Malee KM, Kammerer BL, Wilkins ML, Rutstein R, Tassiopoulos K, Chernoff MC, Mellins CA (2015) Executive functioning in children and adolescents with perinatal HIV infection. Pediatr Infect Dis J 34:969-975

Nichols SL, Chernoff MC, Malee KM, Sirois PA, Woods SP, Williams PL, Yildirim C, Delis D, Kammerer B (2016) Executive functioning in children and adolescents with perinatal HIV infection and perinatal HIV exposure. J Pediatric Infect Dis Soc 5:S15-s23

Nowakowski RS, Rakic P (1981) The site of origin and route and rate of migration of neurons to the hippocampal region of the rhesus monkey. J Comp Neurol 196:129-154
Pandey HS, Seth P (2019) Friends turn foe-astrocytes contribute to neuronal damage in neuroAIDS. J Mol Neurosci 69:286-297

Paolicelli RC, Bolasco G, Pagani F, Maggi L, Scianni M, Panzanelli P, Giustetto M, Ferreira TA, Guiducci E, Dumas L, Ragozzino D, Gross CT (2011) Synaptic pruning by microglia is necessary for normal brain development. Science 333:1456-1458

Paolicelli RC, Ferretti MT (2017) Function and dysfunction of microglia during brain development: consequences for synapses and neural circuits. Front Synaptic Neurosci 9:9

Paolicelli RC, Gross CT (2011) Microglia in development: linking brain wiring to brain environment. Neuron Glia Biol 7:77-83

Paxinos G, Huang X, Petrides M, Toga A (2008) The rhesus monkey brain. In Stereotaxic Coordinates, Second, Edition. San Diego, California USA, Academic Press

Pearson DA, McGrath NM, Nozyce M, Nichols SL, Raskino C, Brouwers P, Lifschitz MC, Baker CJ, Englund JA (2000). Predicting HIV disease progression in children using measures of neuropsychological and neurological functioning. Pediatric AIDS clinical trials 152 study team. Pediatrics 106:E76

Perez-Garijo A, Fuchs Y, Steller H (2013) Apoptotic cells can induce non-autonomous apoptosis through the TNF pathway. Elife 2:e01004

Petrides M, Pandya DN (1999) Dorsolateral prefrontal cortex: comparative cytoarchitectonic analysis in the human and the macaque brain and corticocortical connection patterns. Eur J Neurosci 11:1011-1036

Petrides M, Tomaiuolo F, Yeterian EH, Pandya DN (2012) The prefrontal cortex: comparative architectonic organization in the human and the macaque monkey brains. Cortex 48:46-57

Phillips N, Amos T, Kuo C, Hoare J, Ipser J, Thomas KG, Stein DJ (2016) HIv-associated cognitive impairment in perinatally infected children: a meta-analysis. Pediatrics 138

Rajkowska G, Goldman-Rakic PS (1995a) Cytoarchitectonic definition of prefrontal areas in the normal human cortex: I. Remapping of areas 9 and 46 using quantitative criteria. Cereb Cortex $5: 307-322$

Rajkowska G, Goldman-Rakic PS (1995b) Cytoarchitectonic definition of prefrontal areas in the normal human cortex: II. Variability in locations of areas 9 and 46 and relationship to the Talairach Coordinate System. Cereb Cortex 5:323-337

Rakic P (1978) Neuronal migration and contact guidance in the primate telencephalon. Postgrad Med J 54(Suppl 1):25-40

Rollins NC, Ndirangu J, Bland RM, Coutsoudis A, Coovadia HM, Newell ML (2013) Exclusive breastfeeding, diarrhoeal morbidity and all-cause mortality in infants of HIV-infected and HIV uninfected mothers: an intervention cohort study in KwaZulu Natal, South Africa. PLoS One 8:e81307

Saito Y, Sharer LR, Epstein LG, Michaels J, Mintz M, Louder M, Golding K, Cvetkovich TA, Blumberg BM (1994) Overexpression of nef as a marker for restricted HIV-1 infection of astrocytes in postmortem pediatric central nervous tissues. Neurology 44:474-481

Sarma MK, Keller MA, Macey PM, Michalik DE, Hayes J, NielsenSaines K, Deville J, Church JA, Walot I, Albert Thomas M (2019) White matter microstructure among perinatally HIVinfected youth: a diffusion tensor imaging study. J Neurovirol 25:313-323

Sarma MK, Nagarajan R, Keller MA, Kumar R, Nielsen-Saines K, Michalik DE, Deville J, Church JA, Thomas MA (2014) Regional brain gray and white matter changes in perinatally HIV-infected adolescents. Neuroimage Clin 4:29-34

Saylor D, Dickens AM, Sacktor N, Haughey N, Slusher B, Pletnikov M, Mankowski JL, Brown A, Volsky DJ, McArthur JC (2016) HIVassociated neurocognitive disorder-pathogenesis and prospects for treatment. Nat Rev Neurol 12:309 
Shan L, Zhang T, Fan K, Cai W, Liu H (2021) Astrocyte-neuron signaling in synaptogenesis. Front Cell Dev Biol 9:680301

Sirois PA, Chernoff MC, Malee KM, Garvie PA, Harris LL, Williams PL, Woods SP, Nozyce ML, Kammerer BL, Yildirim C, Nichols SL (2016) Associations of memory and executive functioning with academic and adaptive functioning among youth with perinatal HIV exposure and/or infection. J Pediatric Infect Dis Soc 5:S24-s32

Smith R, Malee K, Leighty R, Brouwers P, Mellins C, Hittelman J, Chase C, Blasini I (2006) Effects of perinatal HIV infection and associated risk factors on cognitive development among young children. Pediatrics 117:851-862

Sohn AH, Hazra R (2013) The changing epidemiology of the global paediatric HIV epidemic: keeping track of perinatally HIVinfected adolescents. J Int AIDS Soc 16:18555

Speidell A, Asuni GP, Avdoshina V, Scognamiglio S, Forcelli P, Mocchetti I (2019) Reversal of cognitive impairment in gp120 transgenic mice by the removal of the $\mathrm{p} 75$ neurotrophin receptor. Front Cell Neurosci 13:398

Spencer-Smith M, Anderson V (2009) Healthy and abnormal development of the prefrontal cortex. Dev Neurorehabil 12:279-297

Ton H, Xiong H (2013) Astrocyte dysfunctions and HIV-1 neurotoxicity. J AIDS Clin Res 4:255

Tornatore C, Chandra R, Berger JR, Major EO (1994) HIV-1 infection of subcortical astrocytes in the pediatric central nervous system. Neurology 44:481-487

Trillo-Pazos G, Diamanturos A, Rislove L, Menza T, Chao W, Belem P, Sadiq S, Morgello S, Sharer L, Volsky DJ (2003) Detection of HIV-1 DNA in microglia/macrophages, astrocytes and neurons isolated from brain tissue with HIV-1 encephalitis by laser capture microdissection. Brain Pathol 13:144-154

UNAIDS (2020) 2020 Global AIDS update-seizing the momenttackling entrenched inequalities to end epidemics. UNAIDS, Geneva

UNAIDS-2014 (2014) 90-90-90 An ambitious treatment target to help end the AIDS epidemic. Joint United Nations Programme on HIV/AIDS (UNAIDS)

van Arnhem LA, Bunders MJ, Scherpbier HJ, Majoie CB, Reneman L, Frinking O, Poll-The BT, Kuijpers TW, Pajkrt D (2013) Neurologic abnormalities in HIV-1 infected children in the era of combination antiretroviral therapy. PLoS One 8:e64398

Van den Hof M, Ter Haar AM, Caan MWA, Spijker R, van der Lee JH, Pajkrt D (2019a) Brain structure of perinatally HIV-infected patients on long-term treatment: a systematic review. Neurol Clin Pract 9:433-442

Van den Hof M, Ter Haar AM, Scherpbier HJ, Reiss P, Wit F, Oostrom KJ, Pajkrt D (2019b) Lower IQ and poorer cognitive profiles in treated perinatally HIV-infected children is irrespective of having a background of international adoption. PLoS One 14:e0224930

Van den Hof M, Ter Haar AM, Scherpbier HJ, van der Lee JH, Reiss P, Wit F, Oostrom KJ, Pajkrt D (2020) Neurocognitive development in perinatally human immunodeficiency virus-infected adolescents on long-term treatment, compared to healthy matched controls: a longitudinal study. Clin Infect Dis 70:1364-1371
Van Rie A, Harrington PR, Dow A, Robertson K (2007) Neurologic and neurodevelopmental manifestations of pediatric HIV/AIDS: a global perspective. Eur J Paediatr Neurol 11:1-9

Van Rie A, Mupuala A, Dow A (2008) Impact of the HIV/AIDS epidemic on the neurodevelopment of preschool-aged children in Kinshasa, Democratic Republic of the Congo. Pediatrics 122:e123-e128

Voss AK, Strasser A (2020) The essentials of developmental apoptosis. F1000Res 9

Walker KA, Brown GG (2018) HIV-associated executive dysfunction in the era of modern antiretroviral therapy: a systematic review and meta-analysis. J Clin Exp Neuropsychol 40:357-376

Walker SY, Pierre RB, Christie CD, Chang SM (2013) Neurocognitive function in HIV-positive children in a developing country. Int $\mathrm{J}$ Infect Dis 17:e862-e867

Weber V, Radeloff D, Reimers B, Salzmann-Manrique E, Bader P, Schwabe D, Königs C (2017) Neurocognitive development in HIV-positive children is correlated with plasma viral loads in early childhood. Medicine (Baltimore) 96:e6867

Wenzel ED, Avdoshina V, Mocchetti I (2019) HIV-associated neurodegeneration: exploitation of the neuronal cytoskeleton. J Neurovirol 25:301-312

West MJ, Gundersen HJ (1990) Unbiased stereological estimation of the number of neurons in the human hippocampus. J Comp Neurol 296:1-22

Willen EJ, Cuadra A, Arheart KL, Post MJ, Govind V (2017) Young adults perinatally infected with HIV perform more poorly on measures of executive functioning and motor speed than ethnically matched healthy controls. AIDS Care 29:387-393

Yadav SK, Gupta RK, Garg RK, Venkatesh V, Gupta PK, Singh AK, Hashem S, Al-Sulaiti A, Kaura D, Wang E, Marincola FM, Haris M (2017) Altered structural brain changes and neurocognitive performance in pediatric HIV. Neuroimage Clin 14:316-322

Yadav SK, Gupta RK, Hashem S, Bhat AA, Garg RK, Venkatesh V, Gupta PK, Singh AK, Chaturvedi S, Ahmed SN, Azeem MW, Haris $M(2018)$ Changes in resting-state functional brain activity are associated with waning cognitive functions in HIV-infected children. Neuroimage Clin 20:1204-1210

Zash RM, Shapiro RL, Leidner J, Wester C, McAdam AJ, Hodinka RL, Thior I, Moffat C, Makhema J, McIntosh K, Essex M, Lockman S (2016) The aetiology of diarrhoea, pneumonia and respiratory colonization of HIV-exposed infants randomized to breast- or formula-feeding. Paediatr Int Child Health 36:189-197

Zhou D, Masliah E, Spector SA (2011) Autophagy is increased in postmortem brains of persons with HIV-1-associated encephalitis. J Infect Dis 203:1647-1657

Publisher's Note Springer Nature remains neutral with regard to jurisdictional claims in published maps and institutional affiliations. 